\title{
ANALYSING ENGLISH ONLINE RESOURCES FOR CHILDREN: A PRACTICAL CASE WITH AN EVALUATION TEMPLATE PROPOSAL
}

\section{ANÁLISIS DE RECURSOS ONLINE EN INGLÉS PARA NIÑOS: UN CASO PRÁCTICO CON UNA PROPUESTA DE PLANTILLA DE EVALUACIÓN}

\author{
Dra. Cristina Castillo Rodríguez ${ }^{1}$ \\ cristina.castillo@unir.net \\ Beatriz Arias Montañana ${ }^{2}$ \\ barias@fpmislata.com
${ }^{1}$ Universidad Internacional de La Rioja. Facultad de Educación. Avda. de la Paz, 137, 26006 Logroño (La Rioja)
${ }^{2}$ Centro Integrado Público de Formación Profesional MISLATA.
C/ Dolores Ibarruril, 32, 46920 Mislata (Valencia)

\begin{abstract}
Internet provides us, as teachers, with a wide range of tools and resources for practising English in an online environment. However, due to the vast amount of digital resources at our disposal today, and taking into account that not everything found on the net is reliable, we have no other option but to evaluate the resources. On the other hand, on the net we can find several already-created templates for analysing online resources. But, quite often, most of these templates include many indicators that will make the task of evaluating more time consuming, or do not include indicators for assessing the adequacy of the site as far as level, theme and linguistic skills of a foreign language, in our case, English, are concerned. The purpose of this paper is to propose a template enabling ESL or EFL teachers to gather suitable information per online resource and also to analyse some real sites in accordance with the parameters and indicators of the template.
\end{abstract}

Keywords: English, information sources, information technology, foreign languages, online searching.

Resumen: Internet nos ofrece a los docentes una gran variedad de herramientas y recursos para practicar inglés en un entorno online. Sin embargo, debido a la gran cantidad de recursos digitales que están a nuestra disposición, y teniendo en cuenta que no todo lo que se encuentra en la red es fiable, no tenemos otra opción que evaluar nosotros mismos estos recursos. Por otro lado, en la red podemos encontrar plantillas creadas para analizar recursos online. Pero, a menudo, muchas de estas plantillas incluyen muchos indicadores que requieren mucho tiempo para su evaluación o bien no contemplan indicadores para evaluar la idoneidad del recurso en lo que respecta a nivel, temática y destrezas lingüísticas de una lengua extranjera, en nuestro caso, inglés. El objetivo de este artículo es proponer una plantilla que posibilite a los docentes de inglés como segunda lengua/lengua extranjera reunir suficiente información de cada recurso digital y analizar también algunos recursos reales de acuerdo con los parámetros e indicadores propuestos en la plantilla.

Palabras clave: inglés, fuente de información, tecnología de la información, lengua extranjera, búsqueda en línea. 


\section{Introduction.}

Teaching-learning process implies, today, taking into account several methodologies and also a wide range of materials and resources for the perfect acquisition of contents from subjects belonging to a concrete field of knowledge.

In fact, as far as the process of learning in children is concerned, it would be ideal to search for methods and resources so that those young students could enjoy at the same time that they are learning, fostering, thus, their motivation as well.

Current technology offers a wide range of possibilities inside the classroom environment. Besides, young students feel motivated when using technologies in the classroom. On the other hand, we, as teachers, should take into account that young students perceive certain issues differently as we do, above all, because they are considered nowadays as digital natives, according to Prensky's terminology (2001).

Taking into account some premises exposed by Medina (2009) and also the profiles of our students nowadays (Prensky, 2001), we must list some aspects that will influence the adequacy of the content selected in a resource for an effective learning:

-Connecting new information with students' background;

-Highlighting the most important aspects;

-Establishing a logical order of the content;

-Organising content;

-Showing information in different contexts;

-Maintaining the attention of children;

-Using images and pictures to present information.

Apart from these essential aspects, we should bare in mind that students need other external resources for keeping updated in their daily practice with the aim of continuouing with their learning at home after school. And these resources must be selected carefully by teachers. That is why in this paper we are concerned about this issue because not everything found on the Internet is reliable for our potential users: our students from preschool and primary-school education. In this paper we suggest a template for evaluating resources devoted to learning English for young students. However, for implementing the template, the practice of evaluation we will consider in the paper is related to the analysis of resources that will be used by primary-school students.

\section{The importance of using digital online resources.}

According to Hall (2010), digital tools and resources should be used properly. But the improvement of the use of technology in learning environments will succeed only if we have a clear idea about its benefits; therefore, it is important to have a great organisation and planification. Some of the advantages pointed out by Hall (2010) when using online resources are the following:

the process of teaching and learning becomes easier;

. $\quad$ tasks become more entertaining;

- the quality is improved;

- our students turn more active participants of their own learning;

students are more motivated;

parents are provided with more valuable resources for being used with their children.

Nowadays, we know that young students obtain many benefits when using technologies and multimedia resources for acquiring knowledge and a lifelong learning. 
However, even though the advantages of using technologies for learning are very interesting, we, as teachers and parents, should bear in mind that it is also necessary to control the time our students spend in these online activities in order not to lose the social component in their lives.

Sancho (2008) considers that the most important aspect is to transform the most sophisticated ICT in tools belonging to Learning Knowledge Technology (LKT) (Coombs, 2004). Besides, Sancho (2008) states that there is evidence that digital tools and resources could improve learning in certain subjects such as English, Science, Design, and Technology. On the other hand, the success in learning is not utterly due to the use of digital and online resources; other reasons for success are the important role of the teaching methods, the attitute of teachers and students, previous background and experience, the scenario in which children are involved, among others.

Downes (2005) claims that the Internet and Web 2.0 have transformed our lives and, consequently, our students' lives, since knowledge is not static but versatile and it can vary. That is why it is important to give students the tools required for a lifelong learning. Moreover, one of the most important tools we have at our disposal is the Internet, which is considered, somehow, the star tool of all the ICT tools. According to Colás (2003), the Internet is a great influence in education and its use allows us to have a wider vision of education enabling learning in multiculturality, as frontiers are now broken and varied content can be accessed. All of this leads us to describe the profile of students nowadays in the context of technological era.

\subsection{Students' new profile}

As mentioned before, students and children, in general, are considered today digital natives (Prensky, 2001): they were born surrounded by digital resources and technological devices. On the other side, teachers and parents are called digital immigrants, who have adapted to some extent to the use of technology today; so there is a generation divide.

For Prensky (2001), some of the most remarkable characteristics of digital natives are:

they are used to receiving information faster than digital immigrants;

. they are multitaskers;

- they prefer images or graphics and figures rather than text;

. $\quad$ they work online in a comfortable way;

- they improve with frequent or immediate rewards;

. they prefer playing for learning rather than working.

Nevertheless, not all the authors share the idea that multitasks are adequate and appropriate for children. L'Ecuyer (2012) defends that we have to respect the rhythm of children in a more and more demanding and frenetic environment. Also, in other studies, like Medina (2009) shows, multitask is confirmed to be a myth since results of a work are significantly worse when they are carried out by checking different sources at the same time.

The future, however, includes inevitably the use of software, hardware, nanotechnology, robotics, etc., as well as politics, languages, sociology, etc. The fields change and teachers must be prepared to assume them.

A very interesting idea of Prensky (2001) is to adapt contents to computer games, as it is 
a language known by children and students. As far as this idea is concerned, the concept of gamification has also invaded classrooms and there have been some studies around this term (see, for example, current research on the topic provided by Hamari, Koivisto \& Sarsa, 2014)

On the other hand, we have to consider today that educational work of parents and teachers must be complementary and a shared task. This implies a greater communication between both agents by means of a constructive-information tool allowing them to work together in a common project: orientation and education of students. We have to promote autonomy, rules and norms, but also skill and ability development for learning and for life, in general. In the family context, means of communication have a great influence as well as ICT. Therefore, it is essential to teach students their possibilities and the correct use of them in every context (Maestre, 2009).

In primary-school classrooms we find different levels of English in students depending on the aid they receive outside the centre with the new language. Parents are generally concerned about not being able to help their children in the area of English language when they do not know the language. Therefore, it is interesting to have attractive and easy-to-navigate resources appropriate for children.

On the other hand, as Silió (2013) points out, most of primary-school students receive some help for carrying out their homework. Besides, extra-curricular activities are not devoted to practising some sports, but some learning centres for reinforcing conceptual aspects of a certain subject. What is interesting in this type of extra sessions is the quality rather than quantity. Therefore, a good planning and selection of activities could be relevant for attracting our students to the learning of English.

\subsection{Digital-content assessment}

Internet is an endless bank of genuine materials. However, using the resources we find on the net has some advantages and disadvantages. That is why, today, it seems essential the evaluation of digital resources due to the amount of them at our disposal. It became, indeed, a discipline of Documentation Sciences, which was born in the 90s when the World Wide Web appeared as a valuable resource (Codina, 2006). In 2000 Codina already foresaw that the growth of the Internet would imply necessarily more criteria for evaluating digital resources (Codina, 2000). And he was not wrong: the explosion of the Internet and the Web 2.0. (a term coined by O'Reilly, 2005), in our society and, therefore, in the educational system, have allowed us, as teachers, to be creators of genuine resources, and to become users since most of the online resources published on the Internet by individual user/s or educational associations offer some free access to their content.

Burgos (2011) states that educational open resources are freeware and usually shared through the Internet for increasing knowledge, abilities and attitudes, and he adds that these resources can be books, videos, articles, exams, software, activities, etc. As Salvador (2001) claims, we find it very easy to publish our materials and resources on the Internet in a free way; that is why evaluating them thoroughly by considering the potential users (our students) and the purposes we pursue when using those 
resources turns out to be an essential task in our academic and educational role.

On the other hand, the most common practice of a user to search for genuine materials is to type some keywords, according to his/her purposes, in a search engine (like the well-known Google) and take the first results thrown by the latter (Kriscautzky \& Ferreiro, 2014). But this does not guarantee having a list of resources with a certain level of quality.

For assessing the quality of a site, we must have clear that it has to combine good content and a good organization of that content (Ayuso \& Martínez, 2006). However, there are several authors who have proposed their own criteria and indicators for assessing digital resources.

Salvador (2001) establishes two main criteria: 1) Quality of the information; and 2) Quality of the site: Form. The indicators per criterion are the following:

1) Quality of the information:

o Authorship: some information about the author of the site must be provided, as well as some details for contact.

o Characteristics of the information: content must be accurate, updated, objective, and well written.

2) Quality of the site: Form

o Accessibility: the site must allow a fast access to content.

o Usability: the site must be well organised, well designed, easy to navigate, and if it includes links, they must be working properly.

On the other hand, apart from the criteria and indicators, when we are evaluating a resource we should be conscious that we are also adding value as some additional information is assigned to the knowledge it transmits. This way, the experience and personal judgement of the evaluator is going to be incorporated to every evaluation criterion. We can, thus, obtain some more complete information through a clear, explicative and simple writing (Burgos, 2011).

Burgos (2011) also uses the concept of rubric, which is an instrument commonly known because it assesses students' knowledge and their effort when performing a task (Gatica-Lara \& Uribarren-Berrueta, 2012) to propose seven ways for evaluating an open educative resource from different points of view in accordance with some criteria:

1) Quality of content (rubric 1): content must be written correctly and objectively and not present errors.

2) Motivation (rubric 2): resources must be interesting as far as the topics presented are concerned.

3) Design and presentation (rubric 3): resources must offer an organised structure, suitable colours of the background and text, and font must allow readable content.

4) Usability (rubric 4): resources must be easy to navigate in the different pages offered, with an intuitive interface.

5) Accessibility (rubric 5): resources must allow access from different devices, for example, computers, laptops, tablets, smartphones, etc.

6) Educative value (rubric 6): resources must be useful for learning and all the content is shown clearly and accuretly.

7) Global evaluation (rubric 7): resources must show their utility in a context with educative purposes.

According to Red.es (2005), it is advisable to list all the features and requirements a resource should have before evaluating it. After that, the evaluator can assign a system of percentages or points for every requirement 
and some space for providing some comments or additional observation which cannot be evaluated quantitatively.

Santos $(2015 ; 2016)$ based her analysis of educational sites on a Model of Evaluation of the Quality of Educational Websites (EQEWS). The author explains that this model can be divided into a) Functional aspects, in which five criteria are considered in the evaluation of sites: Authority, Update, Usability, Accessibility, and Communication; and b) Technical and aesthetic aspects, where other five criteria are assessed: Graphic design and multimedia quality, Content, Navigation, Speed of access and Interaction.

Codina (2000) is one of the most cited authors as far as the evaluation of websites is concerned. The author proposes two main criteria: content and authorship. However, each one has some concrete indicators which play a specific role in the evaluation of sites. Some years later, Codina (2008) suggests a 9parameter template for evaluating digital resources providing an example of evaluation.

However, Codina $(2000 ; 2008)$ indicates that, in general, an evaluator must consider three main parts when assessing a site: Identification (with all the information related to the site: URL, title, aims of the site and theme, author/source; and potential users); Analysis (with parameters and indicators to consider in the evaluation); Conclusions (with some strong and weak aspects of the site, recommendations, etc.).

Seghiri (2016) proposes another genuine template, on the basis of the suggestions proposed by other authors. In this case, Seghiri (2016) proposes for her template three main parameters: authorship, content, and design and ergonomics. In the case of websites for learning a second or foreign language, other authors have proposed their own criteria for assessing sites, for example, Dogoriti and Pagge (2012) as well as Kir and Kayak (2013), in the case of English, and Michira (2017), for Swahili language.

\section{Methodology: The design of an evaluation template.}

Teachers, in their role of online resource evaluators, must consider certain aspects when assessing a site for their students. In this section, we will propose and describe a template with some parameters and indicators for assessing resources according to our purposes. The template has been designed on the basis of the parameters and indicators proposed by other authors, the appropriateness of the contents focused on the field of English learning, as well as our potential users and their characteristics.

Besides, we should bear in mind that our main aim is to offer a useful evaluation template which allows teachers of English as a second or foreign language to carry out a selection of the resources for primary-school students in the fastest and the most efficient way.

\subsection{Tool}

The evaluation template proposed in this paper contains five parameters: Identification, Adequacy, General quality, Educative value, and Remarkable aspects. Three of them (Adequacy, General Quality, and Educative value) have some indicators in which the evaluator will assign some punctuation that ranges from 1 (lowest mark) to 5 (highest mark). Identification and Remarkable aspects are parameters not based on quantitative aspects, so no points will be assigned there. 


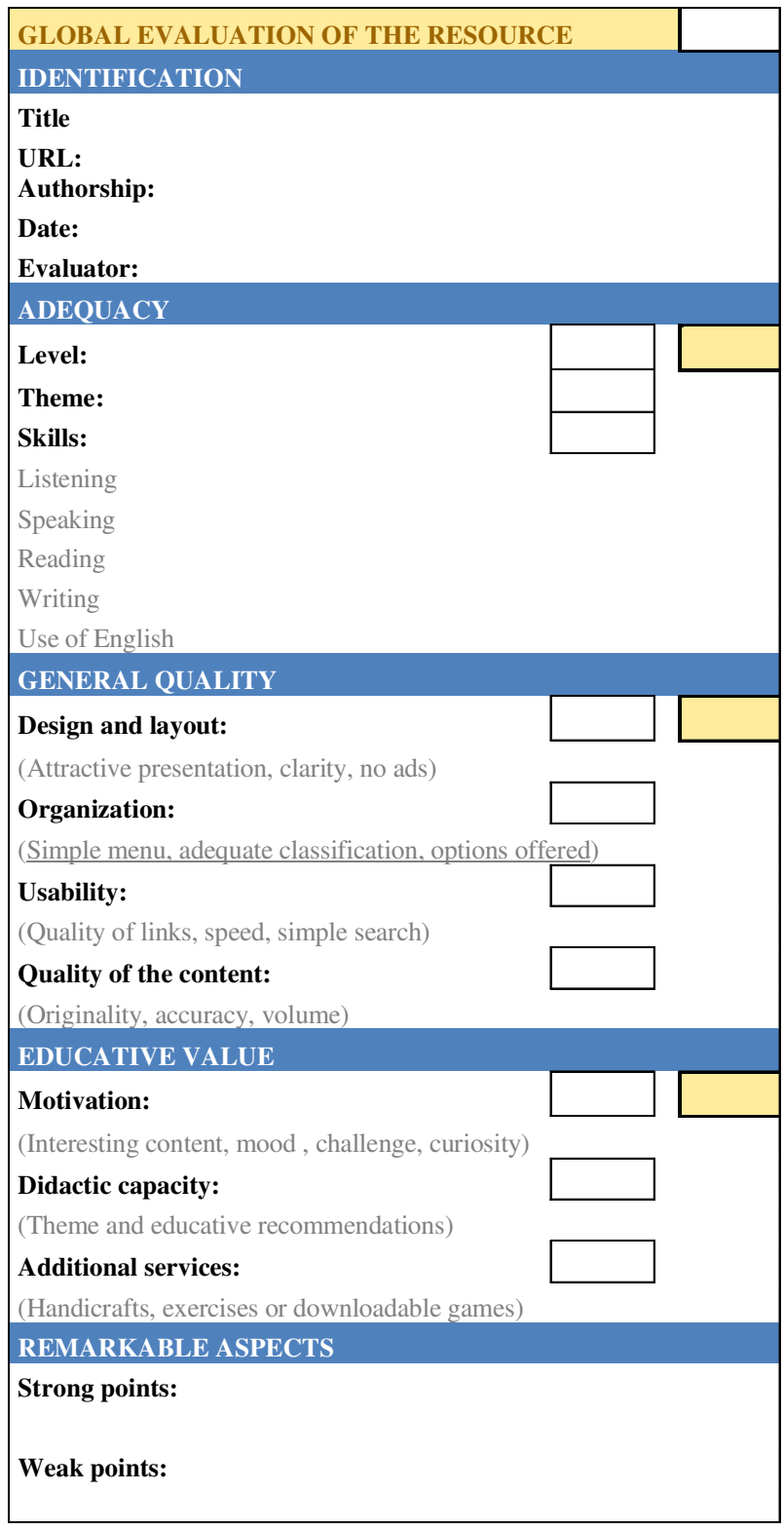

Table 1. Template for evaluating online resources 
Therefore, the total punctuation that a resource can obtain is 50 points. Next table (Table 1) shows the design of our template:

Let us describe one by one the parameters involved in the template.

Parameter 1. Identification

Identification is devoted to collect some basic information from the resource: the title, the URL, and the authorship (author or authors who created the website). Additionally, information about the name of the evaluator and the date of the evaluation will be included in this parameter of the template.

Parameter 2. Adequacy

There are three indicators to evaluate: level, theme, and skills.

a) Level. The complexity of the resource taking into account the grade in which it will be used is evaluated here. If the site is perfectly adapted to the level we are immersed, it will obtain 5 points. When it does not reach the necessary requirements, but students can perform it, it will obtain 4 or 3 points. If it is extremely difficult or easy, the resource can be assigned 2 or 1 point, depending on the degree of difficulty the evaluator considers when checking the content of the resource.

b) Theme. Topics of the content must be appropriate for the level of education in which the site will be used. Therefore, evaluators must take into account topics for every stage of education.

c) Skills. Each skill is assigned one point, depending on what is practised in the site. The four linguistic skills (listening, speaking, reading, and writing) are considered, as well as a fifth element called use of English, in which grammar and other lexical aspects are included.

The total punctuation for Adequacy parameter is 15 points.
Parameter 3. General quality

This parameter offers a general idea of the quality of the site. Therefore, aspects concerning the design and layout, organization, usability, and quality of the content are indicators to be considered in the evaluation:

a) Design and layout. The design should help in the correct processing of the information. Therefore, textual, audiovisual, and graphic layout must be taken into account. Textual elements must keep a special distribution with the aim of clarifying their identification, with a relevant heading and clear structured writing. Videos and animations should include some brief description of the content to facilitate its selection and serve as an introduction for a better comprehension in the student. Graphics must be labelled and ordered in a correct way for providing armony together with the colour, design, and music, without interferring with the aims of the resource. Clarity and absence of publicity will be valued positively.

b) Organization. The menu of options must be clear and simple in order to identify quickly all the possibilities offered without leading to errors and misunderstandings. A correct classification of the contents must be performed. It will also be valued positively if all the options are shown without moving the pointer, since this could lead to wrongly think that there are no more possibilities to choose. Another aspect in the item is if the labels with the possibilities are appropriate and if it is known every moment where the user is found. That is to say, the menu is always available with the opportunity of going back or chaning the option. If the system of navigation is coherent or it has certain logic and the same textual labels and iconic resources for 


\begin{tabular}{|c|c|c|c|c|c|c|c|c|c|c|}
\hline \multirow{2}{*}{\begin{tabular}{|l|} 
Key word \\
Website \\
\end{tabular}} & \multicolumn{10}{|c|}{ English for kids } \\
\hline & 1 & 2 & 3 & 4 & 5 & 6 & 7 & 8 & 9 & 10 \\
\hline \multicolumn{11}{|c|}{ GLOBAL EVALUATION OF THE RESOURCE } \\
\hline Punctuation & 48 & 39 & 35 & 45 & 27 & 20 & 25 & 34 & 35 & 28 \\
\hline \multicolumn{11}{|c|}{ ADEQUACY (Primary Education) } \\
\hline Punctuation in the section & 14 & 14 & 14 & 13 & 9 & 9 & 9 & 12 & 14 & 8 \\
\hline Level & 5 & 5 & 5 & 4 & 1 & 2 & 4 & 4 & 5 & 1 \\
\hline Theme & 5 & 5 & 5 & 5 & 5 & 4 & 4 & 4 & 5 & 4 \\
\hline Capacities & 4 & 4 & 4 & 4 & 3 & 3 & 1 & 4 & 4 & 3 \\
\hline \multicolumn{11}{|c|}{ GENERAL QUALITY } \\
\hline Punctuation in the section & 20 & 12 & 8 & 19 & 8 & 5 & 10 & 12 & 8 & 10 \\
\hline Design and layout & 5 & 3 & 1 & 4 & 2 & 1 & 2 & 4 & 1 & 3 \\
\hline Organization & 5 & 4 & 1 & 5 & 1 & 1 & 3 & 2 & 1 & 3 \\
\hline Usability & 5 & 2 & 2 & 5 & 2 & 2 & 3 & 2 & 2 & 1 \\
\hline Quality of the content & 5 & 3 & 4 & 5 & 3 & 1 & 2 & 4 & 4 & 3 \\
\hline \multicolumn{11}{|c|}{ EDUCATIVE VALUE } \\
\hline Punctuation in the section & 14 & 13 & 13 & 13 & 10 & 6 & 6 & 10 & 13 & 10 \\
\hline Motivation & 4 & 4 & 4 & 4 & 2 & 2 & 3 & 3 & 4 & 3 \\
\hline Didactic capacity & 5 & 4 & 4 & 4 & 3 & 2 & 3 & 4 & 4 & 4 \\
\hline Additional services & 5 & 5 & 5 & 5 & 5 & 2 & 0 & 3 & 5 & 3 \\
\hline
\end{tabular}

Table 2. Evaluation results for the online resources thrown with the key words English for kids

representing the same functions are always used.

c) Usability. The resource must load quickly. Its graphics or multimedia applications should not reduce the speed of the site making the user wait for visualizing the whole page. The quality of links is also an aspect to highlight, since they must offer high-quality contents and they should be correctly connected. A search option of contents in order to find easily the resources of a certain topic, for example, would be also valuable.

d) Quality of the content. This indicator deals with the absence of errors and the accuracy of the contents. Originality will be also taken into account when assessing a site, for example, if it offers unique information or activities such as infographics, games, exercises... and not links directed to other resources. Another aspect to evaluate here is the quantity of varied activities and content offered by the site.

The total punctuation for General Quality parameter is 20 points.

Parameter 4. Educative value

This parameter is devoted to assessing if the site contributes to increase students' knowledge or reinforce their learning. A site could be apparently beautiful and attractive for students and even entertaining, but it might not add some educative value. Therefore, some other indicators should be considered. It is important to observe the 


\begin{tabular}{|c|c|c|c|c|c|c|c|c|c|c|}
\hline \multirow{2}{*}{$\begin{array}{l}\text { Key word } \\
\text { Website } \\
\end{array}$} & \multicolumn{10}{|c|}{ ESL for children } \\
\hline & 11 & 12 & 13 & 14 & 15 & 16 & 17 & 18 & 19 & 20 \\
\hline \multicolumn{11}{|c|}{ GLOBAL EVALUATION OF THE RESOURCE } \\
\hline Punctuation & 35 & 31 & 42 & 17 & 21 & 9 & 25 & 27 & 17 & 27 \\
\hline \multicolumn{11}{|c|}{ ADEQUACY (Primary Education) } \\
\hline Punctuation in the section & 12 & 12 & 14 & 6 & 8 & 3 & 12 & 9 & 5 & 8 \\
\hline Level & 4 & 4 & 5 & 2 & 3 & 1 & 4 & 4 & 1 & 3 \\
\hline Theme & 4 & 4 & 5 & 2 & 2 & 1 & 4 & 4 & 2 & 3 \\
\hline Skills & 4 & 4 & 4 & 2 & 3 & 1 & 4 & 1 & 2 & 2 \\
\hline \multicolumn{11}{|c|}{ GENERAL QUALITY } \\
\hline Punctuation in the section & 12 & 10 & 16 & 7 & 6 & 3 & 8 & 10 & 8 & 12 \\
\hline Design and layout & 3 & 3 & 4 & 1 & 1 & 1 & 2 & 2 & 2 & 3 \\
\hline Organization & 3 & 2 & 4 & 2 & 1 & 1 & 2 & 2 & 2 & 3 \\
\hline Usability & 3 & 2 & 4 & 2 & 1 & 0 & 2 & 2 & 2 & 4 \\
\hline Quality of the content & 3 & 3 & 4 & 2 & 3 & 1 & 2 & 4 & 2 & 2 \\
\hline \multicolumn{11}{|c|}{ EDUCATIVE VALUE } \\
\hline Punctuation in the section & 9 & 9 & 12 & 4 & 7 & 3 & 5 & 8 & 4 & 7 \\
\hline Motivation & 3 & 3 & 4 & 1 & 2 & 1 & 2 & 3 & 0 & 2 \\
\hline Didactic capacity & 3 & 3 & 4 & 1 & 3 & 1 & 1 & 3 & 2 & 2 \\
\hline Additional services & 3 & 3 & 4 & 2 & 2 & 1 & 2 & 2 & 2 & 3 \\
\hline
\end{tabular}

Table 3. Evaluation results for online resources with the key words ESL for children

concepts included in the activities and the capacity to achieve the purpose.

a) Motivation. The indicator deals with the capacity for causing interest in the student for the activity in which he/she is involved, as this way his/her efficiency will increase too. A motivating resource must be based generally on situations closed to the age and level of children and stimulate their interest through curiosity, mood, drama, or challenges. A student has been motivated when showing greater interest for the topic after having worked with the resource.

b) Didactic capacity. The utility of the resource for generating or improving learning in the theme tackled there will be evaluated.
The information must be presented in a clear and concise way, even with some recommendations for the use of the activity in the teaching practice. The perception of the utility in the educative context must be further evident, for example, presenting relevant content related with educative themes to develop abilities and attitudes.

c) Additional services. An indicator which considers the inclusion of complementary information in order to keep on working on the contents without Internet connection: activities to print, downloadable games, instructions to carry out some handicrafts, among others. 


\begin{tabular}{|c|c|c|c|c|c|c|c|c|c|c|}
\hline \multirow{2}{*}{$\begin{array}{l}\text { Key words } \\
\text { Website }\end{array}$} & \multicolumn{10}{|c|}{ Learning English } \\
\hline & 21 & 22 & 23 & 24 & 25 & 26 & 27 & 28 & 29 & 30 \\
\hline \multicolumn{11}{|c|}{ GLOBAL EVALUATION OF THE RESOURCE } \\
\hline Punctuation & 32 & 35 & 19 & 21 & 20 & 14 & 26 & 22 & 37 & 14 \\
\hline \multicolumn{11}{|c|}{ ADEQUACY (Primary Education) } \\
\hline Punctuation in the section & 8 & 10 & 1 & 7 & 6 & 5 & 8 & 9 & 10 & 4 \\
\hline Level & 2 & 3 & 0 & 2 & 2 & 2 & 3 & 1 & 4 & 2 \\
\hline Theme & 2 & 3 & 0 & 1 & 1 & 1 & 2 & 4 & 4 & 1 \\
\hline Skills & 4 & 4 & 1 & 4 & 3 & 2 & 3 & 4 & 2 & 1 \\
\hline \multicolumn{11}{|c|}{ GENERAL QUALITY } \\
\hline Punctuation in the section & 16 & 17 & 16 & 11 & 8 & 5 & 13 & 8 & 13 & 5 \\
\hline Design and layout & 4 & 4 & 4 & 3 & 1 & 1 & 3 & 2 & 3 & 1 \\
\hline Organization & 4 & 4 & 4 & 3 & 2 & 1 & 3 & 2 & 3 & 1 \\
\hline Usability & 4 & 4 & 4 & 3 & 2 & 1 & 4 & 2 & 3 & 1 \\
\hline Quality of the content & 4 & 5 & 4 & 2 & 3 & 2 & 3 & 2 & 4 & 2 \\
\hline \multicolumn{11}{|c|}{ EDUCATIVE VALUE } \\
\hline Punctuation in the section & 8 & 8 & 2 & 3 & 6 & 4 & 5 & 5 & 14 & 5 \\
\hline Motivation & 2 & 2 & 1 & 1 & 1 & 1 & 1 & 2 & 5 & 1 \\
\hline Didactic capacity & 3 & 3 & 1 & 1 & 3 & 2 & 2 & 1 & 4 & 2 \\
\hline Additional services & 3 & 3 & 0 & 1 & 2 & 1 & 2 & 2 & 5 & 2 \\
\hline
\end{tabular}

Table 4. Evaluation results of online resources with the key words Learning English

The maximum punctuation in Educative Value parameter is 15 points.

Parameter 5. Remarkable aspects

This parameter does not contemplate numeric mark, as it is proposed for describing some informative or qualitative function in order to complement the global evaluation of the site. Strong and weak aspects of the site will be indicated. In this parameter, the evaluator can provide other additional valuable comments about other interesting features not considered in previous parameters, or even if the total punctuation in the three parameters before is very low but the resource has some interesting feature to be included in a list of resources.

\subsection{Procedure and sample}

The search engine Google has been used for searching for online resources in order to practise English in primary-school education. The list of resources has been built by the results obtained in that search engine when typing some key words.

First of all, we have typed English for kids and we have selected the ten first websites; secondly, ESL for children, and other ten websites from the first results thrown by the search engine have been chosen; and thirdly, Learning English is the sequence of key words typed for obtaining more results, but 
only the ten first results have been chosen again.

Therefore, a total of 30 sites have been chosen, analysed and evaluated with the template proposed and described before (see Appendix for visualizing the list of websites analysed in this paper). These online resources have been collected between December 2016 and January 2017.

In the following section the complete analysis and the whole punctuation obtained per resource are explained in detail.

\section{Results: Empirical analysis of English online resources.}

The first ten results thrown by Google with the key words English for kids have been evaluated with the template proposed in this paper. The punctuation obtained per site is shown in the following table (Table 2).

As far as the Remarkable aspects, we have provided some valuable assessment as strong aspects: site 1 offers videos with related activities; site 2 shows some great variety of activities; site 3 proposes games in groups; site 4 gathers some pieces of advice for carrying out activities in class without computers; and, finally, site 10 presents interesting exercises for reading and for practising phonemes.

As weak aspects, we have highlighted some sites: sites 3 and 5 are less accessible because of the poor organization of their content; site 7 only has songs; and site 8 is very slow.

The second list of ten sites thrown once typed ESL for children in the search engine has obtained the results shown in the following table (Table 3).

The most remarkable strong aspects of these ten resources are: sites 11 and 15 contain some printable flashcards with vocabulary and some printable games, respectively; site 13 offers a great variety of entertaining exercises and songs with activities; site 16 offers some interesting downloadable presentations and games for groups; site 18 proposes suggests some stimulating ideas for performing some theatre plays in the English class; in site 19 there are some links to sites so that children can learn English;

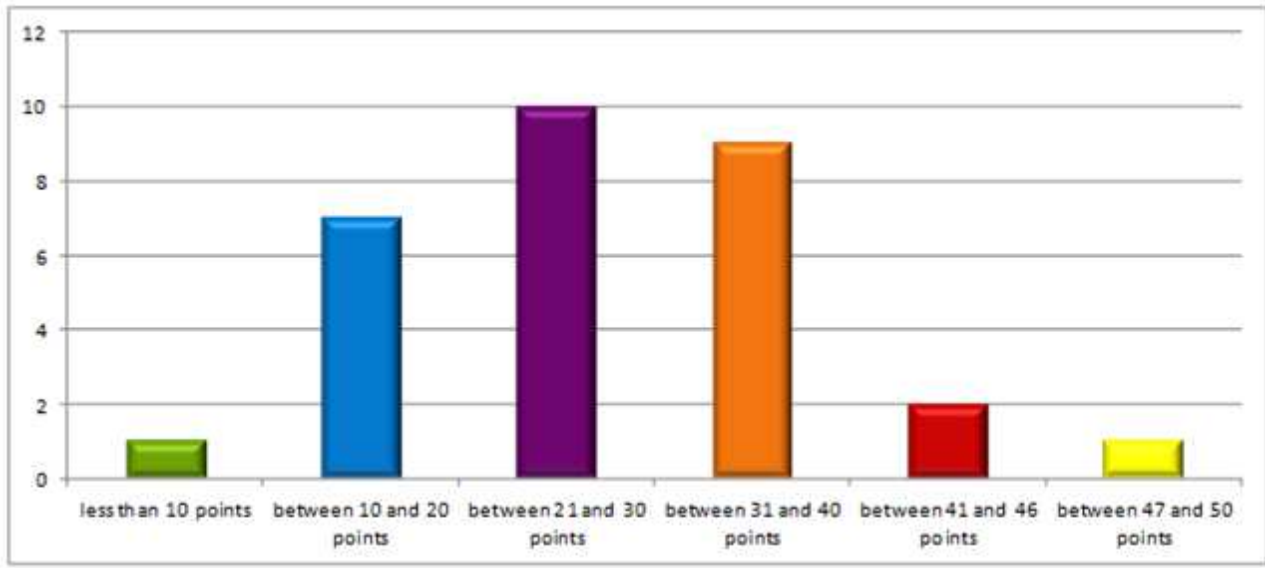

Figure 1. Global evaluation of the sites 


\begin{tabular}{lll}
\hline Site 1 & LearnEnglish Kids & 48 \\
\hline Site 4 & Fun English Games & 45 \\
\hline Site 13 & ESL Kids stuff & 42 \\
\hline Site 2 & Angliomacy.pl & 39 \\
\hline Site 29 & Games to learn English & 37 \\
\hline Site 3 & English 4 kids & 35 \\
\hline Site 9 & ESL Kids lab & 35 \\
\hline Site 11 & ESL-Kids & 35 \\
\hline Site 22 & LearnEnglish (British Council) & 35 \\
\hline Site 8 & English for little children & 34 \\
\hline
\end{tabular}

Table 5. Best valued resources

and site 20 is remarkable for its songs and games with videos showing how they work in the classroom environment.

Weak aspects in this list have been also found in sites $11,12,16$, and 17, which offer a lot of ads; site 14 is not devoted to students whose mother tongue is not English; site 18 has very little content; and site 19 is more devoted to offering resources in English for adult students.

Finally, the third list of resources selected when typing Learning English in the seach box of Google has obtained the following punctuation (Table 4).

In this last group of sites, the strong aspects that can be highlighted are the following: sites 22 and 29 gathers some games for learning English; site 25 shows some vocabulary exercises; and site 28 provides information about the British culture.

As weak aspects, we can stress that most of the resources show an advanced level for primary-school students, except for site 29 , whose adequacy to the level is more appropriate than the rest of sites of the list.

On the basis of the punctuation observed before in the tables, we have established for global evaluation six groups of punctuation: less than 10 points (insufficient); between 10 and 20 points (unsatisfactory); between 21 and 30 points (sufficient); between 31 and 40 points (satisfactory); between 41 and 46 points (very good); and between 47 and 50 points (excellent).

The sites with good punctuation, or those obtaining more than half of the maximum punctuation (those from the groups between 31 and 40, between 41 and 46, and between 47 and 50) constitute the $40 \%$ of the sites evaluated before, being, then, the $60 \%$ the sites obtaining not very good punctuation. Therefore, we can highlight the main role of the teachers when selecting the most adequate material for their students, since, although there are a great amount of resources, not all of them turn out to be appropriate. On the other hand, this figure might not be significant, since, as stated before, there are many factors a teacher should take into account in the evaluation of resources. Besides, there is also a section in our template to indicate any relevant observation of the site.

If we order the sites by their global punctuation, we can extract the 10 best valued 


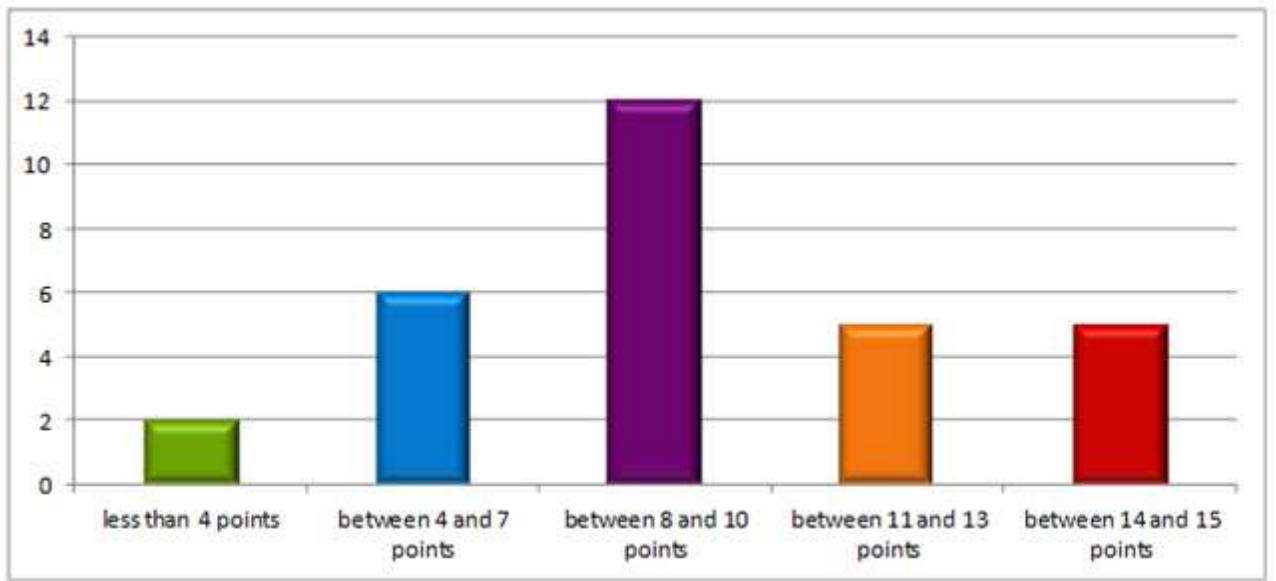

Figure 2. Adequacy

sites. The following table shows the sites that have obtained the highest punctuation.

Even though most of the well-valued websites held the first positions in Google, we can observe that it is not always like this, so it is interesting to carry out a deep search and a thorough analysis when we need an adequate resource for our class.
We have also looked at the different parameters, and have observed the results obtained in the different sites. In Adequacy parameter we have considered Primary Education. The results (Figure 2) have been grouped in five ranges of points, being the maximum punctuation 15 : less than 4 points; between 4 and 7 points; between 8 and 10

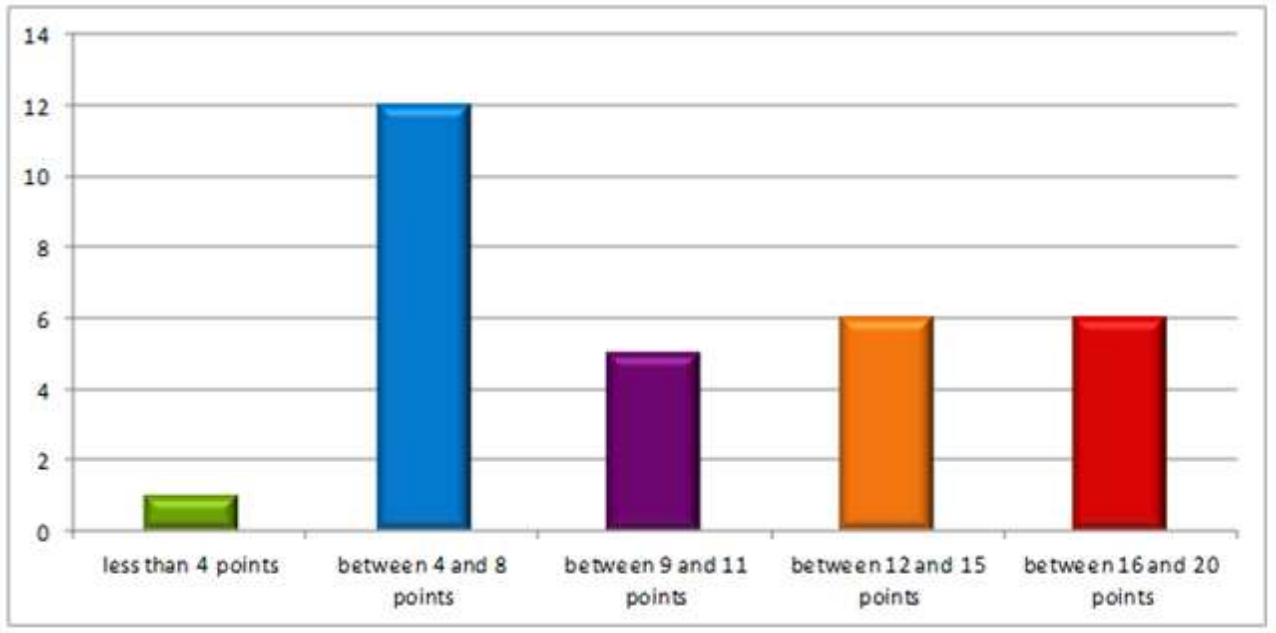

Figure 3. General quality 


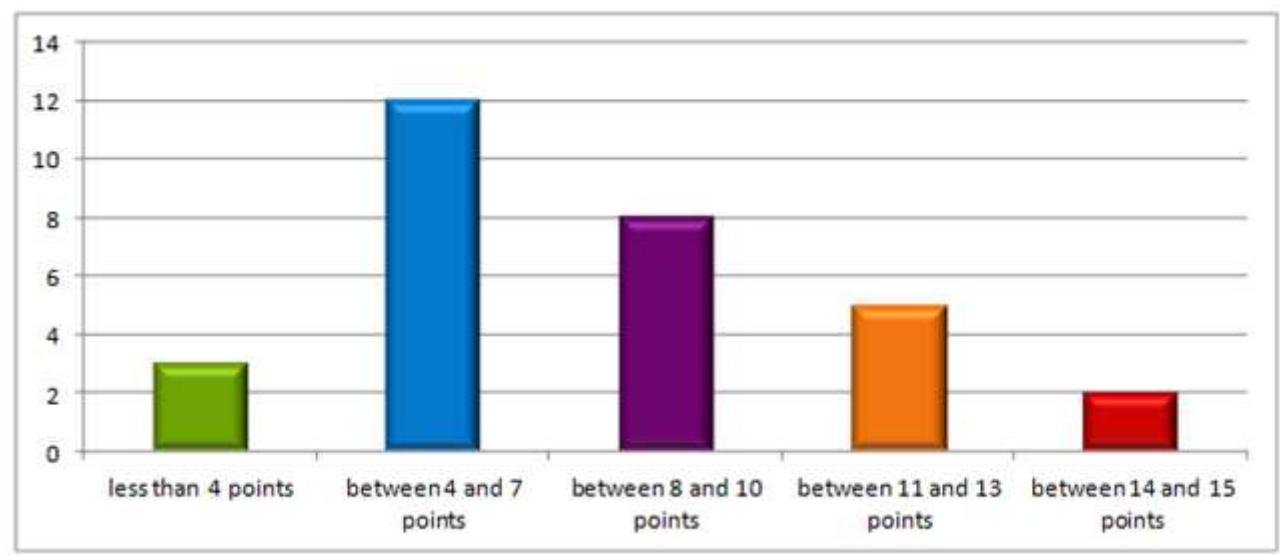

Figure 4. Educative value

points; between 11 and 13 points; and between 14 and 15 points.

The sites with good or very high punctuation constitute the $56.67 \%$, contrasting this result with the global evaluation before (40\%). We can deduct that although it could be a very important parameter, we can find websites with an appropriate adequacy but with a poor quality in general or little educative value.
The following figure (Figure 3 ) offers the outcomes obtained in the parameter General Quality, where the results with the best punctuation, corresponding to groups of points between 12 and 15 , and between 16 and 20 , represent the $40 \%$ of the sites evaluated for this paper. Therefore, most of the sites have shown some problems related to design, organisation, usability, and quality of the content.

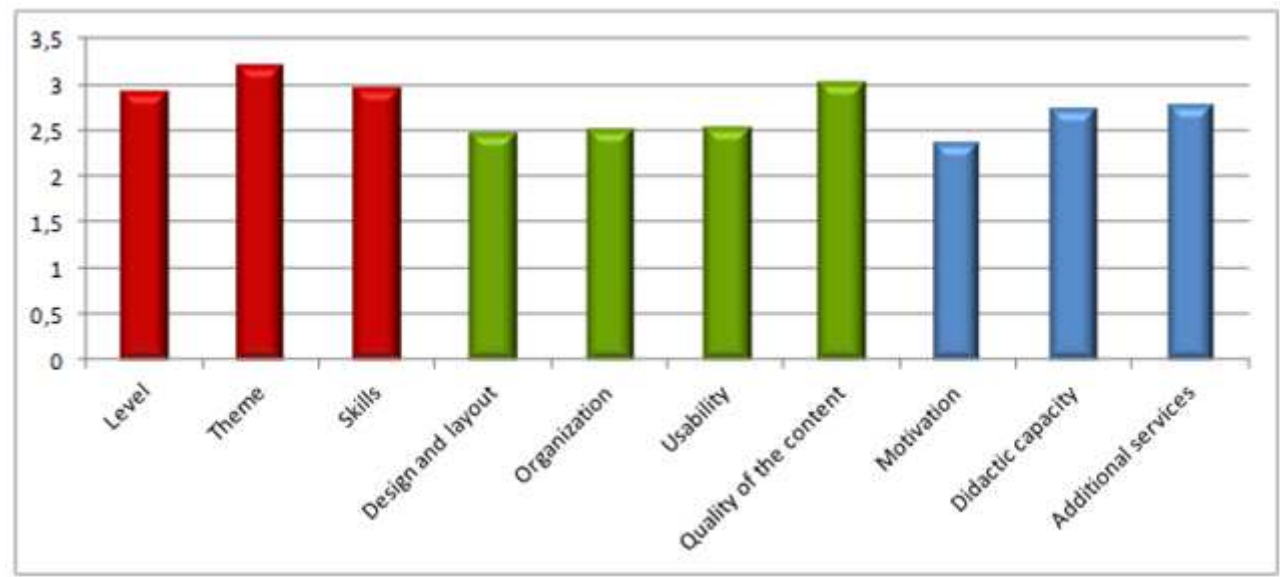

Figure 5. Mean calculated in every item. 
As far as Educative value parameter is concerned in our evaluation template, five groups of points have been proposed (see Figure 4 ). As we can observe, the $50 \%$ of the sites have obtained more than 7 points, being the $23.33 \%$ the sites obtaining good or high punctuation, so it is the item holding less websites with a high or very high punctuation. We can conclude with this that it is a pending challenge for most of the online resources, since achieving the motivation of students is not a simple task, apart from offering educative recommendations and additional services for a better exploitation of these resources.

If we calculate the average of the punctuation obtained in the different indicators individually, the indicator obtaining the best result is the Theme (3.2 points); which means that most of the sites analysed contained activities and content adapted to the real context of primary-school students. However, the indicator with worst evaluation in the template has been the Motivation (2.37 points). As we can deduct, for us, as teachers, it is sometimes very complicated to create some attractive and stimulating content for catching our students' attention.

\section{Conclusion and final remarks.}

Internet has become one of the most consulted tools of all the ICT tools that we, as teachers, have at our disposal. Besides, the Internet, as we know today, has revolutionized the way we teach, as not only can we consult materials and resources published by individuals or organizations, but also we can create our own materials and share them with other people around the world. That is why evaluating digital resources becomes more and more important, because not everything found on the net is reliable and designed for educative purposes.

In this paper we have proposed some parameters and indicators, on the basis of the ones proposed by other relevant authors consulted (for instance, Burgos, 2011; Codina, 2000, 2008), in a template used for evaluating English online resources found on the Internet by using some simple key words in a well-known search engine.

We have obtained all the results of the sites found and have proposed a list of the ten online resources best valued in the analysis performed before. It is interesting to conclude that when assessing an online resource, it is important to have a look at all the parameters and indicators, because some can obtain a worse punctuation in an indicator, and, on the other hand, it might be an excellent resource due to other punctuations obtained in the rest of indicators.

Finally, apart from quantifiable parameters and indicators, having a final parameter for providing additional comments and remarkable aspects of the resource seems useful too, as teachers, in their role of evaluator of websites, can complement the quantitative results obtained in the other parameters with valuable information.

\section{References}

Ayuso García, M.D. \& Martínez Navarro, V. (2006). Metodología de evaluación de recursos en bibliotecas digitales. Parámetros e indicadores de calidad. Ciencias de la información, 37(1). Retrieved from http:// www.redalyc.org/pdf/1814/181418033002.pdf

Burgos Aguilar, J.V. (2011). Rúbricas para evaluar Recursos Educativos Abiertos. Retrieved from http://www.temoa.info/sites/ default/files/OER_Rubrica.pdf 
Codina, L. (2000). Evaluación de recursos digitales en línea: Conceptos, indicadores y métodos. Revista española de documentación científica, 23(1). Retrieved from redc.revistas.csic.es/index.php/redc/ article/viewFile/315/479

Codina, L. (2006). Evaluación de calidad en sitios web: Metodología de proyectos de análisis sectoriales y realización de auditorías (v.2008). Barcelona: UPF. Área de Biblioteconomía y Documentación. Retrieved from http://bit.ly/2oLKuJF

Codina, L. (2008). Metodología de análisis y evaluación de recursos digitales en línea (v. 7). Barcelona: UPF. Sección Ciencias de la Documentación. Retrieved from http://bit.ly/2ocAsUi

Colás, P. (2003). Internet y aprendizaje en la sociedad del conocimiento. Comunicar, 20(1). Retrieved from http://www.redalyc.org/ articulo.oa?id=15802005

Coombs, S. (2004, June). The benefits of introducing a Learning and Knowledge Technology module as part of a core curriculum for postgraduate professional development degrees. Conference paper presented at the Asian Pacific conference: The challenge of integrating JCT in teacher education, University of Jonkoping, Sweden.

Dogoriti, E. \& Pagge, J. (2012). Criteria for the Evaluation of Websites for the Teaching of English as a Second Language. Web Supported English Learning in Greece. 5th International Conference «ICT for Language Learning». Florence, Italy, November 15-16, 2012. Retrieved from http:// conference.pixel-online.net/ICT4LL2012/ common/download/Paper_pdf/454-IBT98FP-Dogoriti-ICT2012.pdf

Downes, S. (2005). An Introduction to Connective Knowledge. Retrieved from http:/ /www.downes.ca/post/33034
Gatica-Lara, F. \& Uribarren-Berrueta, T (2012). ¿Cómo elaborar una rúbrica?. Investigación en Educación Médica, 2(1). Retrieved from http://bit.ly/1m2MXKd

Hall, D. (2010). The ICT Handbook for Primary Teachers: A Guide for Students and Professionals. New York: Routledge.

Hamari, J.; Koivisto, J. \& Sarsa, H. (2014). Does gamification work? A literature review of empirical studies on gamification. In $47^{\text {th }}$ Hawaii Internationa Conference on System Sciences, 3025-3034. Retrieved from doi: 10.1109/HICSS.2014.377

Kir, Elif and Selda Kayak (2013). The Evaluation of Websites Teaching English as a Foreign Language (efl). Procedia - Social and Behavioral Sciences, 106(10), 2788-2795. Retrieved from http://bit.ly/2h5riXI

Kriscautzky, Marina \& Emilia Ferreiro. (2014). La confiabilidad de la información en Internet: criterios declarados y utilizados por jóvenes estudiantes mexicanos. Educação e Pesquisa, 40(4), 913- 934. http://dx.doi.org/ 10.1590/s1517-97022014121511

L'Ecuyer C. (2012). Educar en el asombro. Barcelona: Plataforma editorial.

Maestre Castro, A.B. (2009). Familia y escuela. Los pilares de la educación. Innovación y experiencias educativas, 14(1). Retrieved from http://bit.ly/1dWbgZj

Medina, J. (2009). Brain Rules. New York: Paperback

Michira, James N. (2017). An Evaluation of Websites for Learning Swahili as a Foreign Language. International Journal of Education and Research, 5 (1), 93- 106. http:// www.ijern.com/journal/2017/January-2017/ 08.pdf

O'Reilly, T. (2005). What Is Web 2.0 -Design Patterns and Business Models for the Next Generation of Software. In O'Reilly. 
Spreading the knowledge of innovators. http://bit.ly/200TdlM

Prensky, M. (2001). Digital Natives, Digital Immigrants .On the Horizon, 9(5). Retrieved from http://bit.ly/IMBu0j

Red.es (2005). Ficha de evaluación de material educativo digital. Material no publicado. Retrieved from http://bit.ly/ 2nGBNid

Salvador Oliván, J.A. (2001). Evaluación de recursos de información en Internet: evaluación formal $y$ de contenidos. [Unpublished material]. Retrieved from http:/ /eprints.rclis.org/8727/1/EvaluacionAvila.pdf

Sancho, J.M. (2008). De TIC a TAC, el difícil tránsito de una vocal. Investigación en la Escuela, 64, 19-30.

Santos, A. M. (2015). Theoreticalmethodological proposal to evaluate the quality of educational websites to support education. TEEM '15 Proceedings of the Fourth International Conference on Technological Ecosystems for Enhancing Multiculturality, 397-401. Porto, Portugal, October 07-09, 2015.

Santos, A. M. (2016). Evaluation of educational websites to support primary and high school in Portugal. TEEM '16 Proceedings of the Fourth International Conference on Technological Ecosystems for Enhancing Multiculturality, 261-267. Salamanca, Spain, November 02-04, 2016.

Seghiri Domínguez, M. (2016). Diseño de una plantilla electrónica de evaluación de sedes web científicas para la creación de recursos de enseñanza-aprendizaje (alemáninglés-español). Educatio Siglo XXI, 34(3). Retrieved from http://dx.doi.org/10.6018/j/ 275741
Silió, E. (January, 17th 2013). Ayudarle a hacer los deberes no es ayudarle. El País. Retrieved from http://bit.ly/2p3LUyL 


\section{APPENDIX}

\section{No. Resource name}

1 LearnEnglish Kids

2 Angliomacy.p

3 English 4 kids

$4 \quad$ Fun English Games

$5 \quad$ English for children (blog)

6 Rong Chang ESL

7 Kids songs and stories (blog)

8 English for little children

9 ESL Kids lab

10 Starfall

$11 \quad$ ESL-Kids

12 Teach Children ESL

13 ESL Kids stuff

14 Primary resources

15 About education

16 ESL kids world

$17 \quad$ ESL galaxy

18 ESL Children's Drama Games

19 Dave's ESL Cafe

20 GenkiEnglish

21 Learning English (BBC)

22 LearnEnglish (British Council)

23 Learning English (VOA)

24 La mansión del inglés

25 Englisch Hilfen

26 Lingolex

27 Talk English

28 Leo network

29 Games to learn English

$30 \quad$ Enjoy learning English (blog)

\section{URL}

http://learnenglishkids.britishcouncil.org/

http://www.anglomaniacy.pl/

http://www.english-4kids.com/

http://www.funenglishgames.com/

http://childrenlearningenglish.blogspot.com.es/

http://www.rong-chang.com/kids.htm

http://englikids.blogspot.com

http://bit.ly/1 mzEJsy

http://www.eslkidslab.com/

http://www.starfall.com/

http://esl-kids.com/

http://www.teachchildrenesl.com/ http://www.eslkidstuff.com/ http://www.primaryresources.co.uk/ http://esl.about.com/od/teachingchildren/ http://www.eslkidsworld.com/ http://www.esl-galaxy.com/Kids.htm http://esldramagames.com/ http://www.eslcafe.com/search/Kids/ http://genkienglish.net/lessonplan.htm http://www.bbc.co.uk/learningenglish/ http://learnenglish.britishcouncil.org/en/ http://learningenglish.voanews.com/ http://www.mansioningles.com/ http://www.englisch-hilfen.de/en/ http://www.lingolex.com/espan.htm http://www.talkenglish.com/ http://www.learnenglish.de/ http://gamestolearnenglish.com/ http://enjoy-learningenglish.blogspot.com.es/

Fecha de recepción: 20-04-2017

Fecha de evaluación: 25-04-2017

Fecha de aceptación: 28-07-2017 